\title{
Inter-cognitive Representations in Business Networks
}

\author{
Stefanos Mouzas \\ Lancaster University \\ Management School \\ Lancaster LA1 4YW, UK \\ s.mouzas@lancaster.ac.uk \\ Tel.: +44 (0)1524 593908
}

\author{
Stephan C. Henneberg \\ Business Ecosystems Research Group \\ School of Business and Management \\ Queen Mary University of London \\ London E1 4NS, UK \\ s.henneberg@qmul.ac.uk \\ Tel.: +44 (0)207 8826544
}

\section{Industrial Marketing Management Special Issue \\ Interplay between Cognition, Action and Outcomes in Business Markets \\ Edited by Lars-Gunnar Mattsson, Daniela Corsaro and Carla Ramos}

\author{
Accepted Manuscript \\ Final Revision
}

November 2014

Send correspondence to Stefanos Mouzas, Lancaster University, Management School, Lancaster LA1 4YW, UK. E-mail: s.mouzas@lancaster.ac.uk 


\begin{abstract}
This study aims at conceptualizing the different outcomes of inter-cognitive representations, such as manifestations of agreements between business actors, legally binding contracts, and industry standards and regulations which are developed through interactions between actors in business networks. Inter-cognitive representations inscribe shared understandings and thus prove an objectified basis for further interactions within the business network. To advance the study of inter-cognitive representations in business networks, we develop a conceptual framework that integrates two conceptual dimensions, namely, 1) 'shared understanding of rules' and 2) 'interaction among interdependent actors'. The framework allows us to formulate four theoretical propositions that provide alternative hypotheses, which deserve further research and empirical testing.
\end{abstract}

\title{
KEYWORDS
}

Cognition; Business Networks; Contracts; Rules; Interaction 


\section{Inter-cognitive Representations in Business Networks}

"[E]epistemology [which] is concerned with the prospects of human knowledge must work hand in hand with cognitive science" (Goldman, 1999, p. 280).

\section{INTRODUCTION}

This study conceptualizes the different outcomes of inter-cognitive representations which are developed through interaction between organizations. We use the term intercognitive representations to describe organizational artefacts that inscribe shared understandings, such as manifestations of agreements between business actors, legally binding contracts, industry standards, and business regulations. Notwithstanding the well-rehearsed arguments on the relevance of cognitive representations (Tripsas \& Gavetti, 2000; Gavetti \& Rivkin, 2007; Salvato, 2009) or managers’ subjective cognitive pictures (Corsaro \& Snehota, 2012; Ramos \& Ford, 2001; Henneberg et al., 2006, 2010; Geiger \& Finch, 2010; Leek \& Mason, 2010; Ford et al., 2003) there is a paucity of discussion of the role of inter-cognitive representations developed through interaction practices between business partners (Öberg et al., 2012).

The term representations means per se that an objectified artefact is a model and hence a reduction that is created to represent the complexity of business affairs. As Cooper (1992, p. 257) puts it: "[t]he affairs of the world are made pliable, wieldable and therefore amendable to human use through technologies of representations". In a broader context, intercognitive representations include diverse practices such as accounting rules, public procurement regulations, financial reporting, industrial classifications, and legislation. We also use the term business networks to describe webs of inter-related exchange relationships among organizations (Ford et al., 2003). We thus employ the term network to move beyond 
simple dyadic relationships to examine effects on indirect relationships (Håkansson \& Snehota, 1989; Mouzas, 2006a). In such a business-to-business context, our attention is specifically focused on, first, the business interactions among interdependent actors, and secondly, shared rules that govern these business interactions and thus transcend any individual organizational action or individual managerial cognition.

The present article is based on the following argument: Business interactions between organizations do not occur in a vacuum; interactions are based on shared understandings of the rules that guide actors' behaviours; and the actors are affected by these rules. Shared understandings of rules can refer to a mutually perceived availability of exchange interfaces, trade practices and norms, or shared appreciations and values including explicit or implicit regulations and laws that govern business interactions. Consider in this context the relevance of good faith as a reasonable commercial standard of fair dealings. The threshold requirement of good faith is that each party must negotiate and perform the contract honestly. In case of a misrepresentation, where one counterpart has been induced to enter into a business contract as a result of a false statement of fact by the other party, the shared understanding of the interacting parties is that such misrepresentation can cause to rescind (set aside) that contract. Hence, each actors' interpretation supposes a 'shared understanding', or what Heidegger (1966) described as prejudice. This shared understanding becomes a boundary object, i.e. a tangible or intangible manifestation of a shared understanding of the interaction characteristics in a business relationship (Star \& Griesemer, 1989). Such boundary objects are defining common practices for partners in a business network (e.g. open-book accounting agreements and financial templates used between a manufacturer and its first-tier suppliers; Kajüter \& Kulmala, 2005); they are being interpreted similarly by all sides involved in business 
exchanges (i.e. the cognitive frames of actors are overlapping) and thereby provide organizational boundary-spanning manifestations of shared intent (Mason \& Easton, 2009; Harrison et al., 2011).

In this article, we argue that inter-cognitive representations inscribe shared understandings and thus prove an objectified basis for further interactions within the business network. Previous research (Johanson \& Mattsson, 1992; Weick, 1993, 1995; Welch \& Wilkinson, 2002; Ford et al., 2003; Henneberg et al., 2006, 2010) provides valuable insights about how individuals make sense of a network and how interactions work within it. For example, Henneberg et al. (2010 p. 356) make clear that “managers' cognitive representations of the network and its characteristics can be seen as embracing an individual's 'frame of reference',[...]. However, such sense-making happens via interacting with others, e.g. managers, customers, or other experts". Recent research pushes this inquiry forward by providing empirical evidence of the emergent role of value representations in managing business relationships (Corsaro, 2014). Questions remain about the interplay between cognition, managerial action and outcomes in business networks and how the research based on managers' 'network pictures' (Ford et al., 2003) can be developed to better understand collective decision-making and inter-action in business networks. For example, previous research on cognition and sense-making (see IMM, 2010, Special Issue, Sense-Making and Management in Business Networks) does not explain sufficiently the development of shared understandings in business networks. Such research remains routed in individual cognition, i.e. managers' subjective cognitive views and does not consider the creation of a 'collective mind' in, as well as between, organizations (Weick \& Roberts, 1993). There is thus a need for improved clarity and for a stronger integration of research advances from related disciplines 
such as psychology, economics and strategy with existing conceptualisations of business-tobusiness marketing. What are the determinants of inter-cognitive representations? What are the implications of inter-cognitive representations on interaction in business networks? While our argument does not relate to the process of creating a shared, inter-cognitive understanding, or to the relationship between individual network pictures on the one hand, and inter-cognitive representations on the other, our reasoning is aimed at conceptualizing the different outcomes of such inter-cognitive, shared understanding. The evidence hitherto is that business managers face tremendous difficulties in integrating disperse pieces of individual cognitive views held by various actors in their surrounding business networks (Mouzas et al., 2008). There exists a lack of theoretical discussion regarding the role of shared understandings in business networks. This theoretical deficiency has prevented researchers from investigating the outcomes of the amalgamation of individual perceptions into inter-cognitive representations, which is a pre-condition to getting to grips with collective decision-making and interaction in business networks, such as networking decisions regarding influencing the network position of a firm (Ford et al., 2003; Ford \& Mouzas, 2010, 2013).

As inter-cognitive representations are created through recurrent interactions among actors embedded in networks of exchange relationships, they differ from individual cognitive representations (Tripsas \& Gavetti, 2000) or individual managers' network pictures (Henneberg et al., 2006, 2010). In other words, inter-cognitive representations express the knowledge individual actors have about other actors' knowledge, which is based on interactions between these actors. For this reason, the efficacy of inter-cognitive representations will depend on their prominence or salience (Mehta, Starmer \& Sudgen, 1994). Prominent or salient bearings of what is expected from actors can be found in almost 
every part of organizational life. Vivid examples are industry standards or explicit regulations within certain industries. Organizations, such as the American National Standards Institute (ANSI), the British Standards Institute (BSI), Deutsches Institut für Normung (DIN), or the International Organization for Standardization (ISO), develop inter-cognitive representations of many kinds. For example, ISO 9000 certifications comprise internationally agreed standards of managing a corporation to gain the confidence of customers and other business partners in networks.

Using further practical examples, we illustrate how prominent objectified artefacts such as manifestations of agreements, contracts, industry standards and regulations affect business relationships in networks. Our aim is to provide a theoretical foundation that will enable us to investigate and analyse inter-cognitive representations. For this reason, we propose a conceptual framework for the analysis of objectified artefacts that contributes to the literature on cognitive representations through an inter-cognitive perspective, i.e. a shared inter-organizational and objectified perspective. In this way, the present study answers calls for more research on the amalgamation of individual cognitive approaches to business network representations, both within a firm (i.e. between individual managers; Öberg et al., 2012) and between firms (Henneberg et al., 2010).

The article is organized as follows: An initial discussion of the shared understanding of rules will be followed by an outline of the interactions within business networks. Based on this review, a conceptual framework of inter-cognitive representations is developed, and its theoretical implications are discussed via positing propositions. Managerial implications as well as suggestions for future research conclude our argument. 


\section{A SHARED UNDERSTANDING OF RULES}

In developing a network perspective on rules encountered in business relationships, a study of the constitution of networks (Mouzas \& Ford, 2009) invites us to an imaginative world in which raw material suppliers, manufacturers, equipment suppliers, logistics companies, wholesalers, and retailers would buy and sell goods and services without reliance on any shared system of rules. In this imaginary world there would be no manifestations of business agreements, no legally binding contracts; no industry standards, rules and no regulations regarding fair trade, quality controls, predefined patterns of advertising and promotions, or specified interfaces for logistics. As a result, actors would lack a shared or inter-cognitive understanding of rules, no one would conform to a particular pattern of behavior; and no one would expect other actors to conform to some previously learned pattern (Lewis, 1967; Young, 1993). What would be the problem in this imaginative world? According to Mouzas \& Ford (2009), the problem would not simply be the existence of anarchy, but rather the inherent difficulty for actors of interacting with each other; thereby, the possibility of exchange between actors would be severely constrained (Buchanan, 1975, 1988, 1988; Biggart \& Delbridge, 2004).

In this imaginative world of a business network in which no rules are shared among actors, resources that are needed may not be identified by buying or selling firms (Pfeffer \& Salancik, 1978). Thus, firms would face "prohibitive costs in terms of the time and effort needed to access other actors, to negotiate the terms for interaction, to conclude and manifest deals and to oversee and enforce agreements" (Mouzas \& Ford, 2009, p. 495). In the absence of a shared system of rules among actors, information asymmetry and symmetric ignorance of 
business opportunities would prevent actors from deal-making and building up the business relationships on which their companies depend (Ford \& Håkansson, 2006).

The existence of shared rules is, therefore, important for the functioning of business networks. Shared rules have been evident in trade from the earliest times, and research has provided significant insight into their relevance as the institutional structure of business life (Buchanan, 1975, 1988; Loasby, 2000; North, 1990; Nee, 1998; Loasby, 2000). Extant research raises questions about the real-life nature of rules and the dialectic relation between the structural make-up of rules and the interactions among actors embedded in networks of business relationships. We know, for example, very little about how companies interact with each other; and we lack insights into how the multiplicity of rules is manifested in business relationships.

Previous research (Esser, 1956; Dworkin, 1967; Ayres \& Gertner, 1989; Riley, 2000) suggests that the traditional distinction between ius strictum (i.e. mandatory rules) and ius dispositivum (i.e. yielding rules) that has existed since Roman times is still valid today. This theoretical differentiation corresponds to the contemporary distinction between mandatory and default rules (Ayres \& Gertner, 1989; Riley, 2000). In a similar way, Esser (1956) differentiates between 'Rule' (Norm) and 'Principle' (Grundsatz). The unifying idea of previous research is that continuous replication of existing interaction patterns by interacting counterparts can lead to the development of principles which operate as 'optimization commands' over time (Dworkin, 1967), and thus adopt the characteristic of network rules of conduct. Such rules and principles may, therefore, limit the types of relationships in which the businesses are able to participate (Håkansson \& Ford, 2002; Mouzas \& Ford, 2009). 
A shared understanding of rules increases the 'predictability' of group members' behavior and gives expression to a business network’s 'central values' (Feldman, 1984). Sharing of rules decreases uncertainties and risk, and allows for the development of a 'theory of mind' by actors (i.e. the ability to understand and anticipate other actors' mindset and considerations; Eisenberg, 2006), which takes expectations about reasonable behaviors by relationship partners within the business network into account (Hallen et al., 1991). However, such shared understanding of rules does not come into existence because actors recognize it as a rationally constructed condition. As Hayek described, shared rules evolve because groups of actors that "practiced them were more successful" (1973, p. 18). Thus, a shared understanding of rules evolved through interactions and ensures behavioral regularities, which sustain themselves (i.e. they become self-governing mechanisms), as they serve the interests of the actors involved in business networks. Consequently, a shared understanding of rules refers to the 'rules of the game' or the devised constraints that evolved through and shape human interaction, whether political, social, or economic (Lewis, 1967; North, 1990).

\section{INTERACTION AMONG INTERDEPENDENT ACTORS}

Valuable resources that are necessary for individual actors to solve their problems are widely dispersed across many different actors within the business network, and often within different business networks (Pfeffer \& Salancik, 1978). This dispersion of resources creates strong dependencies between organizations at a time of rapid technological change and global competition for customers and business growth. Therefore, strong interdependencies lead to formidable uncertainties for individual actors and a high degree of unpredictability (Duncan, 1972; Downey et al., 1975; Milliken, 1987). Individual actors can only activate the resources 
they need through interaction within their exchange relationships with others (Barney, 1986; Denrell et al., 2003; Zaefarian et al., 2011). This is particularly relevant because a significant number of business activities occur through strategic alliances, partnerships, R\&D collaborations, and many other forms of continuing supplier and customer relationships (Smith Ring \& Van de Ven, 1994).

In this way, interaction among interdependent actors represents an opportunity for the counterparts to explore heterogeneity in their respective networks (Håkansson et al., 2007, 2009; Pfeffer \& Salancik, 1978). It appears that interaction between organizations transcends inter-personal discussion or communication. Interaction is a substantive process that involves the activities and resources of the involved actors (Håkansson et al., 2009). In this substantive process, exchange (in the narrow sense of transferring resources) can be seen as a possibility and a primary element of socio-economic activity (McGinn \& Keros 2002; Biggart \& Delbridge 2004; Buckley, 2005). In this way, exchange refers to actors' “voluntary agreement involving the offer of any sort of present, continuing, or future utility in exchange for utilities of any sort offered in return" (Weber, 1978, p. 72-73). Consent is, ultimately, the moral component that differentiates between valid and invalid exchanges among individual actors (Barnett, 1986; Markovits, 2004). Therefore, understanding the role of exchange requires a fundamental insight of the ways by which individual actors intentionally seek to represent the creation and appropriation of joint gains (Lepak et al., 2007; Corsaro, 2014). Joint gains are achieved through a negotiation process of 'wise trades' (Bazerman et al., 2001) among actors who have the ability to see the broader picture and the connectedness of activities and resources between organizations. However, such 'wise trade' requires a shift in actors' selfperception from 'self as independent' to 'self as part' of a larger whole (Bigelow, 1992), i.e. 
as an actor within an interdependent business relationship. Developing a better understanding of 'wise trades' requires more research into the role of entitlements or property rights that specify the substance of rights that individual actors may possess, acquire, or transfer in their interactions with other actors (Coase, 1960; Demsetz, 1966; Barnett, 1986).

Similarly, our understanding of the substance of business interaction is still limited. Perhaps this is attributed to our propensity to focus our attention on structural elements of business networks and relationships and hence to neglect the behavioural and cognitive aspects (Henneberg et al., 2010). Therefore, investigating interaction among interdependent actors may serve as a means to move on to a higher aggregation level, from atomistic cognition and individual action (of managers or firms) to shared understandings and collective action (within networks of business relationships). Through interaction over time, resources dispersed in business networks will co-evolve, thereby, enabling dyadic exchange relationships to be connected with other business relationships that give access to other more distant networks of relationships. The connectivity outcomes of interaction are evidenced, for example, in the global networks of financial institutions. Financial networks, which involve investment banks, retail banks, for-profit companies, rating agencies, and private households, exhibit high connectivity among the interacting actors despite the existence of conditions of information asymmetry and unforeseen contingencies.

Understanding interactions between interdependent actors is thus linked to getting to grips with the underlying shared rules, and the representations that manifest (or objectify) these rules. There exists a lack of research in business and network studies on such intercognitive outcomes. An exception is research on the 'cognitive strategic group' literature (Langfeld-Smith, 1992; Reger \& Huff, 1993). However, this strand of research is mainly 
focussing on issues of competition, i.e. relates to the layer of companies that perceive themselves to exhibit similar network positions and network roles (Abrahamsen et al., 2012). A theoretical framework for understanding inter-cognitive representations, in contrast, needs to take into account manifold business relationships in the wider business networks. The following will develop such a framework and derive certain theoretical propositions based on this framework.

\section{A CONCEPTUAL FRAMEWORK: CONSTRUCTS AND DEFINITIONS}

The relevant theoretical input from the two aspects of the 'shared understanding of rules' on the one hand, and 'interaction among interdependent actors' on the other hand are now used to define the theoretical constructs in our attempt to move towards a framework of inter-cognitive representations (see Figure 1). The framework will enable us to distinguish different categories (or contingencies) of inter-cognitive representations, which are used to develop theoretical propositions.

Insert Figure 1 About Here

Inter-cognitive representations are shaped by a) rules and b) interactions at different levels. Rules in the context of our framework constitute a system of conventions that become common among actors (Lewis, 1967; Young, 1993). While some of the rules are strict and mandatory, such as legally binding contracts or explicit regulations within an industry; other rules, such as manifestations of consent or industry standards, may be yielding or merely default (Ayres \& Gertner, 1989; Riley, 2000). Legally binding contracts comprise mandatory 
rules that are created through dyadic interaction between business partners. In contrast, explicit regulations are the accumulated effect of network interactions among multiple actors and may be imposed upon them. Interactions refer to substantive processes by which counterparts relate to each other. Undoubtedly, many business interactions are at dyadic level, for example, dyadic interactions happen within business relationships, such as those between a manufacturer and a key first-tier supplier. However, each dyadic relationship in which an individual actor partakes will be connected with other dyadic relationships (Håkansson \& Snehota, 1989; Parolini, 1999), this will form a structure of network interactions that affects other more distant network areas as well as other networks (Håkansson \& Waluszewski 2002; Håkansson et al., 2007, 2009). In this way, the term network interaction is used to transcend the notion of dyadic interaction by incorporating the effects of business relationships on further interactions outside the focal dyad.

The utility of the proposed framework of inter-cognitive representations presented in Figure 1 is that it allows us to explore four different contingencies: 1) manifestations of consent that are created through dyadic interaction based on default rules, 2) legally binding contracts that are created through dyadic interaction, but are based on mandatory rules which are strict rules and thus legally enforceable, 3) industry standards that are created through network interactions based on default rules, and 4) explicit regulations, e.g. legislation or statutory requirements, that are created through network interaction and constitute mandatory rules applicable to all actors. In the following section, we formulate propositions that link the defined constructs with each other and develop arguments that justify our propositions.

\section{THEORETICAL PROPOSITIONS AND IMPLICATIONS}


Following our conceptual framework, we formulate four theoretical propositions, one for each resulting contingency. These propositions are meant to direct further research as they represent new perspectives on the interplay between cognition, inter-action and outcomes in business networks. They also provide alternative hypotheses that need empirical investigation and verification.

Proposition 1: Manifestations of consent form a baseline of default rules in dyadic interactions.

Default rules articulate a common-sense order of shared conventions (Young, 1993; Choi, 1993). They express customary, expected, often non-legal rules that have been previously agreed and manifested in dyadic interactions among actors (Ayres \& Gertner, 1989; Riley, 2000). How is this 'common-sense order' being formed? Much can be gained by investigating the effect of real-life manifestations of consent e.g. protocols, e-mails, memoranda of understandings or agreements in principle on the formation of default rules over time and assess their effect on business relationships. The evidence hitherto suggests that default rules apply a logic of 'unless otherwise agreed' (Barnett, 1992a), as they operate on bases of pre-existing agreements (Mouzas \& Furmston, 2008; Mouzas \& Blois, 2013). Nonetheless, our understanding of the dynamic link between manifestations of consent and the formation of default rules in dyadic interactions is still limited.

Proposition 2: Legally binding contracts override default rules by creating mandatory rules for the contracting parties. 
Mandatory rules are strict and applicable to all contracting parties. They can relate to contractual agreements about delivery times between supplier and customer, or to offering characteristics. Such legally binding contracts represent the most common boundary object in business relationships. Nonetheless, although mandatory, such rules are not unambiguous, as disputes about the interpretation of agreed contract terms are one of the largest sources of contractual litigation. The evidence hitherto is that in the case of a dispute, a neutral judge, arbitrator or mediator will decide the case adopting the contract as an external standard to expresses the reasonable expectations of parties as they are manifested in the contractual agreement (Steyn, 1997). Contracts, however, may build upon understandings that pre-exist as common practice in a particular context and transform them into a framework for managing business relationships (Macneil, 2000; Mouzas, 2006b). For example, as part of a continuing, long-term business relationship, certain delivery patterns may have come to be reasonably expected by partners, and, therefore, they can transform a default rule into a mandatory one over time. Much can be gained by investigating how contracts in long-term relationships create mandatory rules and assess the effect of mandatory rules on the developmental process of collaborative inter-firm relationships (Smith Ring \& Van de Ven, 1994).

Proposition 3: Industry standards form a baseline of default rules shared by network members.

Industry standards transcend any individual actor or business relationship; they involve customary and expected modalities of interfaces and interactions in networks of business relationships. Brunsson \& Jacobsson (2000) differentiate between three kinds of standards: a) standards about being something (e.g. what constitutes 'profit'), b) standards for what we 
should do, e.g. 'standard operating procedures', and c) standards for what we should have, e.g. insurance, plans, qualifications, quality systems etc. As such, industry standards represent codified default rules shared by most if not all members of a business network about aspects which often relate to crucial and foundational aspects of business systems. Nonetheless, default rules evolve and thus redefine industry standards (Brunsson \& Jacobsson, 2000); we thus need more empirical insights about the dialectic link between industry standards and default rules in business networks.

Proposition 4: Explicit regulations transform pre-existing default rules into mandatory rules that apply to all network members.

Mandatory rules applicable to all network members can be found in statute law, for example, in business law. Many business relationships, such as those between retailers and final consumers, employment contracts, or financial and credit contracts nowadays are not regulated by default rules; they are regulated by explicit regulations, e.g. statutes which do not always conform to individual business-to-business relationship agreements or practices. The increasing importance of codified regulations, as well as the growing importance of statutes, cannot be overlooked. In today's business landscape, such codified regulations may include self-regulatory agreements, such as rules about advertising decency, which become quasi-law for an industry and are adjudicated by an independent body. Similarly, we cannot neglect the importance of international regulations that transform pre-existing default rules into mandatory rules, such as a) the provisions in the Convention on International Sale of Goods (the Vienna Convention), b) the United States’ Uniform Commercial Code and Restatement (second) of Law of Contracts, and c) the gradual emergence of a European Civil Code. 


\section{MANAGERIAL IMPLICATIONS}

This research conceptualized different outcomes of inter-cognitive representations in business networks. The range of inter-cognitive representations is virtually endless. Most obvious examples are manifestations of agreements between business actors, legally binding contracts, industry standards or business regulations that are created and shared through an ongoing dyadic as well as network interactions. We have demonstrated that these outcomes of inter-cognitive representations differ from individual cognitive representations frequently discussed in business marketing (Ford et al., 2003; Henneberg et al., 2006, 2010) and management studies (Tripsas \& Gavetti, 2000; Gavetti \& Rivkin, 2007; Salvato, 2009). Managers need to understand the difference between cognitive representations found in individual presentations, speeches, letters or value propositions in key account programs (Henneberg et al., 2005, 2009), and inter-cognitive representations that manifest a shared understanding, either in business relationships or beyond (Öberg et al., 2012). Managers need to be aware that the process of developing inter-cognitive representations does not occur automatically but can, and arguably needs to be guided carefully to develop a shared understanding. The four theoretical propositions presented in this study demonstrate this. As such, inter-cognitive representations are not just 'coming about' as a by-product of interactions, but they are also outcomes of managerial decisions regarding how they come about, and what content they contain (Smircich \& Stubbart, 1985). Managers and management teams could carry, champion, and mediate the following guiding principles:

Transcend individual cognition: Individual cognition based on previous knowledge is potentially an inherent trap that can be avoided. For example, managers' cognition may 
contain biases and errors of judgement (Kahneman, 1992; Kahneman \& Frederick, 2002; Kahneman \& Tversky, 1979; Kahneman, Slovic \& Tversky, 1983). How can managers challenge their individual 'prejudices'? Managers' assumptions need to be tested and improved through several layers of heedful interactions and exchanges with different actors (Weick \& Roberts, 1993). This will ensure that managerial cognition does not exclude other rationales, motivations, and restrictions, which are not individually held and which might be important for other actors and firms.

Inscribe shared understandings: The inscription of shared understandings in organizational artefacts requires a continuous effort to define the rules that govern interaction with other actors. One way to approach this task is to consider objectified artefacts as work-inprogress or as a recurrent practice of inscribing periodical business reviews, negotiation episodes, and manifestations of agreements (Öberg et al., 2012). Inter-cognitive representations need to become objectified outcomes in form of shared data and shared information so that they can be used practically to foster a shared meaning. Dyadic decisions, such as open-book agreements between supplier and buyer firm, can facilitate such endeavours.

Safeguard against myopia: The achievement of a shared understanding constitutes powerful mechanisms of influence; nonetheless, it may potentially result in myopic herd behaviour. Managers need to be aware that herd behaviour in business networks can be brought about when actors are influenced by other actors and this influence is leading to a great number of actors sharing understandings and acting alike (Mouzas \& Ford, 2012). If whole networks share a myopic perspective, i.e. create a 'cognitive community' without actors being able to challenge some 'certainties' as they become enshrined in industry standards or 
even explicit regulations, this can have detrimental effects especially in cases of external turbulence (Porac et al., 1989).

Following these guiding principles, managers' effort to deal with inter-cognitive representations becomes a way of life. It is an indeterminate managerial effort of constructing and inscribing a shared understanding of default and strict rules through multilateral dyadic but also network interactions.

\section{FUTURE RESEARCH}

The present study conceptualized the outcomes of inter-cognitive representations on the basis of a 1) 'shared understanding of rules' and 2) 'interaction among interdependent actors'. The framework allowed us to formulate four theoretical propositions that deserve further research and empirical testing. Given the inherent lack of attention to the relevance of inter-cognitive representations and the managerial challenge of achieving outcomes of shared understandings, future research could move on from the study of subjective cognitive views (e.g. network pictures) to an investigation of objectified outcomes shared by other actors, e.g. the creation or change of boundary objects in business relationships, or the evolution of regulatory norms for business networks. To advance the study of inter-cognitive representations, researchers could utilize the conceptual dimensions of a) 'shared understanding of rules' and b) 'interaction among interdependent actors' and examine the theoretical constructs and contingencies presented in the proposed theoretical framework (see Figure 1). This examination could also include the interactions between different outcomes of inter-cognitive representations, e.g. how industry standards for business networks may relate to the specifics of contracts in dyadic relationships (Meindl et al., 1994). 
The study of inter-cognitive representations in business networks is now more relevant than ever for three reasons: First, a great deal of business activity nowadays occurs through various forms of alliances, partnerships and collaborations in multiple business relationships (Smith Ring \& Van de Ven, 1994) but we know very little about the 'collective mind' in the business landscape (Weick \& Roberts, 1993). Secondly, the interplay between individual cognition, e.g. managers' network pictures, and the different outcomes of inter-cognitive representations needs to be understood as an integrative part of interactions between actors (Henneberg et al., 2010). Understanding these interactions will help to create a better shared understanding of managerial options within business relationships and wider business networks, i.e. it fosters objectified outcomes or what has been termed 'network insight' (Mouzas et al., 2008). Thirdly, research on inter-cognitive representations will help us understand, explain, and predict the institutional structure of rules that govern interaction in business networks (Buchanan, 1988; North, 1990; Nee, 1998; Khalil, 1995; Loasby, 2000). Mandatory rules, for example, may be imposed on actors, thus, they may reshape interactions among actors (Rindt and Mouzas, 2015). There is a long and fruitful way to go. The present study on inter-cognitive representations in business networks has, hopefully, provided a platform to continue this exploration. 


\section{REFERENCES}

Abrahamsen, M.H., Henneberg, S.C., \& Naude, P. (2012). Using Actor's Perceptions of Network Roles and Positions to Understand Network Dynamics. Industrial Marketing Management, 41(2), 259-269.

Barnett, R. E. (1986). A Consent Theory of Contract. Columbia Law Review, 86(2), 269-321.

Barnett, R. E. (1992a). The Sound of Silence: Default rules and contractual consent. Virginia Law Review, 78, 829-859.

Biggart, N., \& Delbridge, R. (2004). Systems of Exchange. Academy of Management Review, 29(1), 28-49.

Brunsson, N., \& Jacobsson, B. (Eds) (2000). A World of Standards. New York: Oxford University Press.

Buchanan, J. M. (1975). A Contractarian Paradigm for Applying Economic Theory. American Economic Review, 65(2), 225-230.

Buchanan, J. M. (1978). Markets, States, and the Extent of Morals. American Economic Review, 68(2), 364-369.

Buchanan, J. M. (1988). Contractarian Political Economy and Constitution Interpretation. American Economic Review, 78(2), 135-139.

Cooper, R. (1992). Formal Organization as Representation: Remote Control, Displacement and Abbreviation, in Rethinking Organization: New Directions in Organization Theory and Analysis, Reed, M. and Hughes, M., (eds.), Sage, pp. 254-272.

Corsaro, D. (2014). The Emergent Role of Value Representation in Managing Business Relationships. Industrial Marketing Management, 43(6), 985-995.

Ford, D., Gadde, L., \& Håkansson, H. (2003). Managing Business Relationships. Chichester: John Wiley and Sons Ltd.

Ford, D., \& Mouzas, S. (2010). Networking under uncertainty: Concepts and research agenda. Industrial Marketing Management, (39), 956-962.

Ford, D., \& Mouzas, S. (2013). The Theory and Practice of Business Networking. Industrial Marketing Management, (42). 433-442.

Dworkin, R. (1967). The Model of Rules. University of Chicago Law Review, 35, 14-46.

Eisenberg, E. M. (2006). Karl Weick and the Aesthetics of Contingency. Organization Studies, 27(11), 1693-1706. 
Gavetti, G., \& Rivkin, J.W. (2007). On the Origin of Strategy: Action and Cognition over Time. Organization Science, 18(3), 420-439.

Geiger, S., \& Finch, J. (2010). Networks of Mind and Networks of Organizations: The Map Metaphor in Business Network Research. Industrial Marketing Management, 39 (3), 381-389.

Goldman, A. (1999). Epistemology and Cognition, in Wilson \& Keil (Eds.). The MIT Encyclopaedia of Cognitive Sciences, The MIT Press, p. 280.

Håkansson, H., Ford, D., Gadde, L.-E., Snehota I., \& Waluszewski A. (2009). Business in Networks. Chichester, John Wiley.

Håkansson H, \& Waluszewski A, (eds). (2007). Knowledge and Innovation in Business and Industry. The importance of using others. Routledge: London, New York.

Håkansson, H., \& Snehota, I. (1989). No Business is an Island. Scandinavian Journal of Management, 5(3),187-200.

Hallen, L., Johanson, J., \& Sayed-Mohamed, N. (1991). Interfirm adaptation in business relationship. Journal of Marketing, 55(2), 29-37.

Harrison, D., Hoholm, T., Prenkert, F., \& Olsen, P. I. (2011). Boundary Objects in Multi-actor Interactions within Tightly Structured Networks. $27^{\text {th }}$ IMP Conference, Glasgow, Scotland.

Hayek, F. A. (1973). Law Legislation and Liberty. Volume 1, Rules and Order. Chicago: The University of Chicago Press.

Heidegger, M. (1966). Being and Time. Translated by J. Macquarrie and E. Robinson. Oxford: Blackwell.

Henneberg, S. C., Mouzas, S., \& Naudé, P. (2006). Network Pictures - Concepts and Representations. European Journal of Marketing, 40(3/4), 408-429.

Henneberg, S.C., Naudé, P., \& Mouzas, S. (2010). Sense-making and Management in Business Networks- some Observations, Considerations, and a Research Agenda. Industrial Marketing Management, 39 (3), 355-360.

Henneberg, S., Pardo, C., Mouzas, S., \& Naudé, P. (2005). Value Dimensions and Strategies in Dyadic 'Key Relationship Programmes'. In Proceedings on the 21st IMP Conference, Rotterdam, The Netherlands.

Henneberg, S. C., Pardo, C., Mouzas, S., \& Naudé, P. (2009). Value Dimensions and Relationship Postures in Dyadic 'Key Relationship Programmes'. Journal of Marketing Management, 25(5-6), 535-550. 
Johanson, J., \& Mattsson, L.G. (1992). Network Positions and Strategic Action-An Analytic Framework. In B. Axelsson \& G. Easton (Eds.), Industrial networks: A new view of reality (pp. 204-217). London: Routledge.

Kahneman, D. (1992). Reference Points, Anchors, Norms, and Mixed Feelings. Organization Behavior and Human Decision Process, 51, 296-312.

Kahneman, D., \& Frederick, S. (2002). Representativeness revisited: Attribute substitution in intuitive judgment, in T. Gilovich, D. Griffin \& D. Kahneman (Eds.), Heuristics and Biases (pp. 49-81). New York: Cambridge University Press.

Kahneman, D., \& Tversky, A. (1979). Prospect Theory: An Analysis of decisions under Risk. Econometrica, 47, 263-291.

Kahneman, D., Slovic, P. \& Tversky, A. (1982). Judgement under Uncertainty: Heuristics and Biases. New York: Cambridge University Press.

Kajüter, P., \& Kulmala, H. I. (2005). Open-book Accounting in Networks: Potential Achievements and Reasons for Failures, Management Accounting Research, 16 (2), 179-204.

Khalil, E. L. (1995). Institutional Theory of the Firm? Extension and Limitation. Review of Political Economy, 7(1), 43-51.

Langfield-Smith, K. (1992). Exploring the Need for a Shared Cognitive Map. Journal of Management Studies, 19 (3), 349-368.

Leek, S., \& Mason, K. (2010). The Utilization of Network Pictures to Examine a Company's Employees' Perceptions of a Supplier Relationship. Industrial Marketing Management, 39 (3), 400-412.

Lewis, D. (1967). Convention: A Philosophical Study. Cambridge: Harvard University Press.

Loasby, B.J. (2000). Market Institutions and Economic Evolution. Journal of Evolutionary Economics, 10 (3), 297-309.

Macneil, I. R. (2000). Relational Contract Theory: Challenges and queries. Northwestern University Law Review, 94, 877-907.

Markovits, D. (2004). Contract and collaboration. The Yale Law Journal, 113: 1417-1518.

Mason, K., \& Easton, G. (2009). Boundary Objects and Buyer-Seller Relationships. The 25th IMP Conference Euromed Management, Marseilles, France. 
Mehta, J., Starmer, C. \& Sudgen, R. (1994). The nature of salience: An experimental Investigation of pure coordination games. American Economic Review, 84 (3), 658673.

Meindl, J.R., Stubbart, C., \& Porac, J. F. (1994). Cognition Within and Between Organizations: Five Key Questions. Organization Science, 5 (3), 289-293.

Mouzas, S. (2006a). Marketing Action in Networks. European Journal of Marketing, 40 (11/12): 1271-1291.

Mouzas, S. (2006b). Negotiating Umbrella Agreements. Negotiation Journal, 22(3), 279-301.

Mouzas, S., \& Furmston, M. (2008). From Contract to Umbrella Agreement. The Cambridge Law Journal, 67 (1), 37-50.

Mouzas, S., \& Blois, K. (2013). Contract Research Today: Where do we Stand? Industrial Marketing Management, 42 (7), 1057-1062.

Mouzas, S., \& Ford, D. (2006). Managing Relationships in Showery Weather: The role of umbrella agreements. Journal of Business Research, 59, 1248-1256.

Mouzas, S., \& Ford, D. (2009). The Constitution of Networks. Industrial Marketing Management, 38, 495-503.

Mouzas, S., \& Ford, D. (2011). Herd Behaviour in Business Networks. Die Betriebswirtschaft, - Business Administration Review (BARev)-, Heft 6/2011.

Mouzas, S., \& Ford, D. (2012). Leveraging Knowledge Based Resources: The Role of Contracts. Journal of Business Research, 65 (2), 153-191.

Mouzas, S., \& Furmston, M. (2008). From Contract to Umbrella Agreement. Cambridge Law Journal, 67 (1), $37-50$.

Mouzas, S., Henneberg, S. C., \& Naude, P. (2008). Developing Network Insight, Industrial Marketing Management, 37 (2), 167-180.

Neale, M.A., \& Bazerman, M.H. (1991). Cognition and Rationality in Negotiation. New York: Free Press.

Nee, V. (1998). Norms and Networks in Economic and Organizational Performance. American Economic Review, 88 (2), 85-89.

North, D. (1990). Institutions, Institutional Change and Economic Performance. Cambridge: Cambridge University Press. 
Öberg, C., Henneberg, S.C. \& Mouzas, S. (2012). Organizational Inscriptions of Network Pictures: A Meso-level Analysis. Industrial Marketing Management, 41 (8), 12701283

Parolini, C. (1999). The Value Net. New York: John Wiley.

Pfeffer J., \& Salancik, G. R. (1978). The External Control of Organizations. New York: Harper \& Row.

Porac, J.F., Thomas, H., \& Baden-Fuller, C. (1989). Competitive Groups as Cognitive Communities: The Case of the Scottish Knitware Manufacturers. Journal of Management Studies, 26 (4), 397-416.

Reger, R.K., \& Huff, A.S. (1993). Strategic Groups: A Cognitive Perspective. Strategic Management Journal, 14 (2), 103-123. 2.

Rindt, J. \& Mouzas (2015). Exercising Power in Asymmetric Relationships: The Use of Private Rules Private rules in Global Networks. Industrial Marketing Management, forthcoming.

Ritter, T. (2000). A Framework for Analyzing Interconnectedness of Relationships. Industrial Marketing Management, 29 (4), 317-327.

Salvato, C. (2009). Capabilities Unveiled: The Role of Ordinary Activities in the Evolution of Product Development Processes. Organization Science, 20(2), 384-409.

Smircich, L., \& Stubbart, C. (1985). Strategic Management in an Enacted World. Academy of Management Review, 10 (4), 724-736.

Smith Ring, P., \& Van De Ven, A. (1994). Developmental Processes of Cooperative Interorganizational Relationships. Academy of Management Review, 19 (1), 90-118.

Star, S. L., \& Griesemer, J. R. (1989). Institutional Ecology, Translations and boundary Objects: Amateurs and Professionals in Berkeley's Museum of Vertebrate Zoology 1907-39. Social Studies of Science, 19, 387-420.

Tripsas, M., \& Gavetti, G. (2000). Capabilities, Cognition and Inertia: Evidence from Digital Imaging. Strategic Management Journal, 21, 1147-1161.

Weber, M. 1978. Economy and Society. University of California Press, Berkeley.

Weick, K.E. (1993). The Collapse of Sensemaking in the Organizations: The Mann Gulch Disaster. Administrative Science Quarterly, 38: 628-652.

Weick, K.E. (1995). Sensemaking in Organizations. Thousand Oaks, Sage. 
Weick, K.E., \& Roberts, K.H. (1993). Collective Mind in Organizations: Heedful Interrelating on Flight Decks. Administrative Science Quarterly, 38, 357-381

Welch, C., \& Wilkinson, I. (2002). Idea Logics and Network Theory in business marketing, Journal of Business-to-Business Marketing, 9 (3), 27-48.

Young, H.P. (1993). The Evolution of Conventions. Econometrica, 61(1), 57-84.

Zaefarian, G., Henneberg, S. C., \& Naude, P. (2011). Resource Acquisition Strategies in Business Relationships, Industrial Marketing Management, 40 (6), 862-874. 
Figure 1: Inter-Cognitive Representations

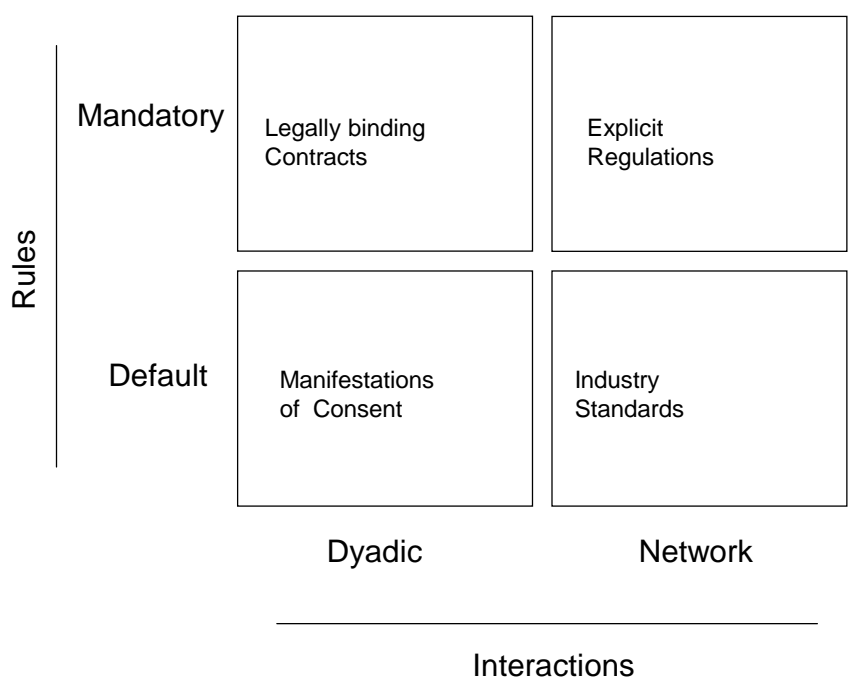

